This migration from mathematics through physics to chemistry made him an excellent holder of the John Humphrey Plummer chair of theoretical chemistry established at Cambridge in 1932. At the same time (1933) he was elected a Fellow of the Royal Society. This post at Cambridge was--and still is-the only chair of theoretical chemistry in Britain. While he was in Cambridge, Lennard-Jones (or 'L.J.' as he was known to his many friends) laid the foundations of the present vigorous school of theoretical studies in Britain. During this time he extended his earlier work on molecular orbitals, he made some useful progress in the very difficult field of chemical interactions at a metal surface, and he developed the 'cage-model' of liquids. Had it not been for the Second World War, in which he played a conspicuous part as Superintendent of Ammament Research and Director-General of Research (Defence) at the Ministry of Supply, there is no doubt but that he would have done even more.

At the end of the War, Sir John returned once more to Cambridge, and although he became chairman of the Scientific Advisory Council of the Ministry of Supply, he and his younger colleagues completed an extensive study of the most fundamental problem in all chemistry-what is meant by a chemical bond? But by this time his administrative abilities were becoming widely known. He was a member of the Advisory Council for the Department of Seientific and Industrial Research, a member of the Scientific Advisory Committee of the National Gallery, and president during $1948-50$ of the Faraday Society. His quiet manner and understanding approach to difficulties made him an excellent chairman on all occasions where conflicting claims had to be reconciled. It was not surprising, therefore, that in April 1953 he was invited to follow the late Lord Lindsay and become the second principal of the new University College of North Staffordshire at Keele. He threw himself whole-heartedly into this work, which he so evidently liked, and in which he had become much appreciated, not only in the College itself, but also in the neighbourhood.

Sir John received many honours. He held the D.Sc. of Manchester and the Sc.D. of Cambridge; he was made K.B.E. in 1946, was awarded the Davy Medal of the Royal Society in 1953, and an honorary D.Se. at Oxford on the occasion of the British Association meeting there only a few weeks before his death, when he was president of Section B (Chemistry). He had recently been awarded the Longstaff Medal of the Chemical Society. All those who knew him respected the complete integrity of his life, the exceptional simplicity and clarity of his lectures and his obvious enjoyment of everything that he did. His home life was a most happy one; he is survived by his widow, a son and a daughter.

C. A. Coulson

\section{Mr. B. H. St. J. O'Neil}

ThE unexpected death on October 24 of Brian Hugh St. John O'Neil at the age of forty-nine has deprived the Ancient Monuments Department in the Ministry of Works of the chief inspector who followed Mr. J. P. Bushe-Fox, whose death was so recently recorded in these pages (Nature, November 6, p. 860).

Educated at Merchant Taylors' School and St. John's College, Oxford, of which he was a scholar, Mr. O'Neil began a career in the City of London, but soon deserted to Westminster and the Ancient Monuments Department in fulfilment of interests always near his heart. His most particular delight was in medieval and post-medieval fortificetions and in early artillery, of which he had a profound and detailed knowledge, well employed, for example, in a recent visit to advise upon the treatment of early Portuguese fortifications in West Africa. He spoke and wrote of these matters with an authority and relish good indeed to meet. But his work extended also with distinction to other fields. He was no mean numismatist, as his classic study of Theodosian silver coin-hoards in late fourth-century Britain proves. $\mathrm{He}$ could take a prominent part in discussions concerning late-Roman copies of earlier coinage. No less notable was his discussion of the Silchester dykes and their relation to Britons and Saxons. Among his field-work should be specially cited his excavation of Frith Ffaldwyn Iron-Age fortress in Fowys and the Caerau settlement in North Wales, and the unstinting unofficial help accorded in the excavations by his wife of Roman villas at Park Street, Whittington Court and Bourton-on-the-Water.

His appointment as chief inspector of ancient monuments brought him into close quarters with war-time and post-war problems in arehrology. The application of State aid to the examination and record of sites threatened by destruction was liberally and wisely interpreted by him, and presently extended to cover sites of national importance which private resources, impoverished by taxation and inflation, were no longer equal to tackling. This was a valiant service to knowledge of which the full effects are not yet apparent, for he was planning publication in promising fashion, talking of the matter with the writer less than a week bofore his death. We have lost far too soon a judicious innovator, a good (if perhaps fatally self-sufficient) administrator, a zealous public servant, a keen scholar and a staunch friend, who in all these capacities will be widely and deeply mourned.

l. A. RichMOND

\section{Miss Rosamund F. Shove}

AFTER a long illness borne with great fortitude, Miss Rosamund F. Shove died on October 17 in Richmond Hospital, aged seventy-six. Until the last few months of her life she had hoped to renew some of her many activities in the field of seience and remained keenly interested to the end. Educated at Girton (1896-99), Miss Shove was trained in research by Prof. A. C. Seward ; and in 1900 "The Morphology of the Stem of Angiopteris erecta" appeared in the Annals of Botany. Miss Shove's professional career included seventeen years of science teaching in schools, followed by twenty years of university and training college work in biology and hygiene. Her last post was at the Maria Grey Training College (1921-38). She served on the council of the Linnean Society during 1943-47.

In 1937 Miss Shove became honorary secretary of the School Nature Study Union, and in 1940 undertook the editorship of its journal, School Nature Study, at a critical time. She sustained both the Union and the journal throughout the War and continued her labours until 1953, when the jubilee number was published. The journal had appeared regularly each quarter, thanks to her tireless devotion.

At the British Film Institute, Miss shove was a faithful member of a volunteer panel who viewed natural history films from many sources. She con- 
tributed many film and book reviews to School Nature Study, besides several illustrated articles based on her discriminating observations; for example, a life-history of a beautiful, ineradicable weed, a pink-flowered Oxalis.

Her small garden at Kew contained many cherished plants, some under glass ; in the large collection of dwarf trees, each in its own pot, are an English elm forty-two years old and a youthful common lime. I was delighted to learn that this collection had been accepted recently for the Royal Botanic Gardens, Kew.

Other evidence of the lasting influence of a gifted botanist will be passed on by her many grateful pupils, students, colleagues and other friends.

Madeline MunRo

\section{NEWS and VIEWS}

\section{Botany at Singapore: $\quad$ Prof. R. E. Holttum}

Prof. R. F. Holtudu, who was the first professor of botany in the University of Malaya, has just retired after spending the greater part of his life in Malaya. He intends to live at Kew, where he will continue his studies on Malayan plants, particularly ferns. Prof. Holttum was born at Linton in Cambridgeshire and was educated at Bootham School, Yorik, and St. John's College, Cambridge. He took the Natural Sciences Tripos with first-class honours in Parts I and II, winning the Frank Smart Prize in 1920. He first went to Malaya in 1922, when he inined_t be staff of the Botanic Gardens. He was

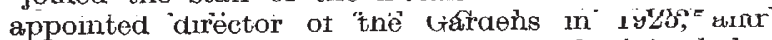
remained at this post until 1949 , when he joined the newly created University of Malaya and brought the Department of Botany into being. Prof. Holttum's appointment was particularly valuable in the early and formative years of the University, for he has travelled widely through Malaya, Borneo and Indonesia and has an unparalleled practical knowledge of the flora of this region. During the past five years he has been very active and has set a tradition that his successor will find it hard to surpass. He has published many papers on ferns, bamboos, gingers and orchids, which are his principal botanical interests, and the past two years have been marked by the publication of some of his major works: "Orchids of Malaya" (Singapore, 1953), "Gardening in the Lowlands of Malaya" (Singapore, 1953), "Plant Life in Malaya" (London, 1954); a fourth volume, "Ferns of Malaya", is in the press. Prof. Holttum's activities in Singapore have been by no means confined to botany, for he has taken a leading part in various important societies. He will be remembered with affection by his students, his colleagues and his many friends in Singapore, who wish him a long and happy retirement near the Royal Botenic Gardens at Kew.

\section{Research in British Power Industries:}

\section{Gas and Electricity}

IN a debate in the House of Commons on November 9 on the annual reports and statements of accounts of the gas and electricity industries, the Minister of Fuel and Power, Mr. Geoffrey Lloyd, said that he had agreed with the Gas Council for capital expenditure this year of $£ 61$ million. Electricity development was estimated by Lord Citrine at $£ 1,250$ million over the next six years; it should provide 1.6 million kilowatts next year and 1.95 million kilowatts in 1959. This includes a five-year programme costing $£ 50$ million to bring electricity to 70 per cent of the farms and 80 per cent of rural housing of Britain. In the first half of this year, industrial consumption of gas increased by 8 per cent and that of electricity by 14 per cent; but the gas industry had saved 250,000 tons of coal last year and the electricity industry 1 million tons. Mr. Lloyd also referred to research on the utilization by the gas industry of inferior and cheaper coals, and to the discovery of a process for making gas from fuel oil alone, for which sixteen new plants are being erected. Questioned by Mr. A. Robens as to whether sufficient money was being spent on research in these two industries, the Parliamentary Secretary to the Ministry, Mr. L. W. Joynson-Hicks, said that the figures quoted by Mr. Robens, $£ 229,000$ for the gas industry and $£ 242,900$ for the electricity industry, did not represent any thing like the full expenditure on research of these two industries. Much of the expenditure, he siid, is

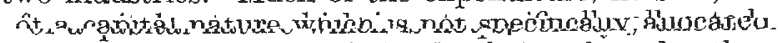
to research ; much work is also being done by the British Electrical and Allied Industries Research Association, and the British Electricity Authority contributes to research being carried out by at least half a dozen other bodies. He promised to attempt to obtain a figure for the total expenditure on research by the industries, but was of opinion that research is not being held up on financial grounds.

\section{Nuclear Power}

MR. LLOYD, referring to nuclear power, emphasized the dependence of industrial power from this source upon the ordinary electricity supply system, the expansion of which is already being planned to feed industry from nuclear power stations when the practical difficulties have been overcome. Mr. Lloyd explained why at present in the experimental atomic power stations steam generation is not closecoupled with the furnace, and also referred to the problem of nuclear fuel and the possibility of utilizing as fuel most of the uranium extracted from the ore. Engineers from the British Electricity Authority are already attending training courses at Harwell, and from now on there will be a steady stream of electrical engineers attending these courses. The British Electricity Authority is collaborating closely with the Atomic Energy Authority, and also with the plant manufacturers, in the design of experimental nuclear power stations by making freely available its experience regarding turbines and power-station construction generally. Mr. Lloyd also said that, with the view of encouraging enterprise and, where proper, a spirit of adventure, the Government has decided to encourage these two nationalized industries to compete with each other as actively as possible and with the oil industry. In the course of the debate, Mr. G. Nabarro expressed the opinion that the prototype and pilot nuclear power station at Calder Hall, with a capacity of $60,000 \mathrm{~kW}$., would be completed by the end of 1956, and that such plants would be making a substantial contribution to grid supplies of electricity well within ten years. Mr. Joynson-Hicks, however, maintained that it would be unreasonable, in view of the vast amount of work and planning to 